\title{
KOMUNIKASI KONFLIK JAWARA BANTEN
}

\author{
Antar Venus ${ }^{1}$, Lukman Saleh Waluyo ${ }^{2}$ \\ ${ }^{1}$ Universitas Padjadjaran \\ ${ }^{2}$ Universitas Pembangunan Nasional Veteran Jakarta
}

Naskah diterima tanggal 10-11-2019, direvisi tanggal 11-12-2019, disetujui tanggal 20-01-2020

\begin{abstract}
Abstrak. Jawara Banten adalah pertemuan budaya lokal yang luar biasa dari bagian budaya orang Indonesia. Mereka membangun standar budaya sendiri yang tidak sama dengan masyarakat Sunda, Betawi, dan Jawa yang memisahkan wilayah tempat tinggal mereka di tepi utara wilayah Banten. Terlepas dari kenyataan bahwa individu-individu ini berasal dari wilayah Cirebon dan Demak yang datang untuk pada abad keenam belas, namun mereka tampaknya mempunyai hubungan sosial dan obudaya yang otentik dengan asal mereka. Penelitian ini dilaksanakan untuk menggali lebih dalam bagaimana cara berkomunikasi Jawara Banten khususnya dalam komunikasi. Metode yang digunakan adalah campuran dari metode paremiologi dan metode wawancara mendalam. Penelitian dilaksanakan selama sembilan bulan (April-Desember 2019) termasuk 12 responden wawancara dan tiga buah buku tentang bahasa Jawa untuk melakukan studi paremiologi. Dari hasil tersebut, peneliti mendapat temuan penelitian sebagai berikut: (1) Komunikasi Jawara Banten konsep besarnya adalah "Deduluran" (2) Selain "Sedulur" ada juga konsep "Sebatur" yang masih turunan dari konsep deduluran. Konsep "Sebatur" ini lebih memperecepat untuk menyelesaikan masalah secara musyawarah dan akhirnya damai. (3) Ada perubahan kultur dalam berkonflik di Banten, kalau dulu berkelahi biasanya ada istilah "wes ijen bae, ijen siji-siji ning alon-alon". Jadi seperti duel dan tidak berkelahi ramai-ramai. Sekarang sudah berkurang karena diselesaikan dulu dengan cara musyawarah. (4) Dalam lingkungan masyarakat Jawara Banten ada larangan yang tidak boleh dilakukan dalam pergaulan antar manusia, ada istilahya "Aje Julid, Aje ngelunjak, Aje Mencangak, Aje Syirika, Aje llok Ngebohong, Aje Ilok Ngulungani, Aje Ilok Makan Uong" karena kurang baik untuk dipakai dalam pergaulan.
\end{abstract}

Kata kunci: Deduluran, Komunikasi, Konflik, Jawara, Banten.

\begin{abstract}
Jawara Banten is an extraordinary local culture from Banten Indonesia. They built their own cultural standards that are not the same as the Sundanese, Betawi, and Javanese who lives nearby. This research was conducted to dig deeper into how Jawara Banten use communication to resolve conflict among them. The method used in this research is a mixture of paremiological methods and in-depth interview methods. The research was carried out for nine months (April-December 2019) using 12 interview respondents and three books on Javanese language to conduct paremiology study. From this research, researchers obtained the following research findings: (1) Jawara Banten communication concept is "Deduluran" (2) Besides "Sedulur" there is also the concept of "Sebatur" which is still a derivative concept of deduluran. The concept of "Sebatur" is used to resolve conflict more quickly and finally can reach for peace. (3) There is a change in how conflict being solved in Banten, where there used to be a fight, it will be solved by a duel fight. Now it was resolved first by communication and discussion between them. (4) In the Banten culture, there are prohibitions that must not be carried out in relationships between people, there is the term "Aje Julid, Aje ngelunjak, Aje mencangak, Aje Syirika, Aje Ilok Ngebohong, Aje Ilok Ngulungani, Aje Ilok Makan Uong" because they are not good to be used in human relationship.
\end{abstract}

Keywords: Deduluran, communication, conflict, Jawara, Banten. 


\section{PENDAHULUAN}

Komunikasi adalah yang membentuk budaya. Melalui komunikasi, kita dapat menemukan apa yang diatur dan dipikirkan secara signifikan oleh suatu budaya. Keyakinan, kualitas, dan perilaku individu di dalamnya tercermin dalam komunikasi. Budaya membentuk contoh dan gaya komunikasi.

Setiap budaya memiliki jenis komunikasi yang unik. Indonesia memiliki banyak sekali etnis, suku, dan budaya. Banten adalah salah satu etnis di Indonesia. Suatu etnis yang dikenal dengan gaya komunikasi yang langsung dan terbuka. Meskipun demikian, dalam kehidupan sehari-hari, Banten memiliki rantai komando sosial yang solid dan ketat.

Banten memiliki kekhasan yang tidak dimiliki oleh masyarakat provinsi lain, khususnya orang-orang yang dikenal sebagai "Jawara" atau "Pendekar" Banten. Jelas bahwa orang-orang Banten, khususnya Jawara memiliki gaya komunikasi yang menarik untuk diteliti, khususnya dalam bagaimana cara mereka menangani konflik yang terjadi di antara mereka.

Adapun tujuan dari penelitian ini adalah untuk mengetahui bagaimana pola komunikasi konflik Jawara Banten dan mengetahui perannya dalam membentuk identitas budaya.

Istilah Jawara di Banten menyinggung individu yang memiliki kualitas fisik dalam pertarungan dan yang memiliki ilmu supranatural seperti kebal dari senjata tajam. Jawara lahir ketika berdampingan dengan para kiai untuk mengusir penjajah Belanda. Setelah penjajahan selesai, ada perubahan signifikan dalam istilah Jawara. Citra Jawara menjadi negatif dan terkesan merendahkan.

Kesan mengerikan tentang Jawara menyebabkan individu-individu yang memiliki ilmu supranatural atau ahli bela diri silat tidak menyebut diri mereka Jawara namun lebih suka disebut dengan pendekar. Mereka mempertahankan posisi sebagai Jawara dengan secara teratur menjaga keamanan wilayah. Di antara Jawara, ada juga rantai komando yang berjalan dari ujung atas Jawara kepada pasukannya. Mereka berbaur dengan masyarakat dan mendapatkan tempat terhormat di tengah-tengah masyarakat. (Firdausi, 2017).

\section{METODE PENELITIAN}

Metode penelitian pada naskah artikel menjelaskan jenis penelitian, subjek dan objek penelitian, waktu dan lokasi penelitian, instrumen penelitian, cara pengambilan sampel, pengumpulan data, dan analisis data.

Metode penelitian pada dasarnya merupakan sebuah cara ilmiah untuk mendapatkan data dengan tujuan dan kegunaan tertentu (Sugiyono 2013).

Metode yang digunakan merupakan gabungan antara metode paremiologi dan metode Wawancara. Penelitian dilakukan selama Sembilan bulan (April-Desember 2019) dengan melibatkan 12 informan untuk wawancara dan tiga naskah buku tentang Bahasa Jawa Banten untuk analisis paremiologi. Informan penelitian pada penelitian ini adalah para Jawara Banten yang bermukim di Banten. Di dalam penelitian ini peneliti akan melakukan wawancara mendalam untuk mengumpulkan informasi.

\section{HASIL DAN PEMBAHASAN}

Hasil penelitian menggambarkan temuan utama dari penelitian. Berdasarkan hasil analisis paremiologi dan wawancara diperoleh temuan penelitian sebagai berikut; Komunikasi Jawara Banten konsep besarnya adalah "Deduluran" jadi seperti kata "Sedulur-Sedulur", "Akur Sedulur", "Aje Ribut Sedulur". Jadi Jawara Banten berkomunikasi menggunakan konsep persaudaraan. Bahkan ketika memanggil tukang becak pun manggilnya "Mang" walaupun tidak ada hubungan saudara atau paman kita tapi maksudnya sudah seperti saudara.

Jawara Banten jika ingin menyelesaikan masalah masih sangat berkaitan dengan cara-cara kekeluargaan, kekeluargannya sangat erat. Sehingga jika ada masalah diselesaikan dengan cara musyawarah.

Jadi karena konflik merusak silaturahim maka penyelesaian menggunakan istilah "deduluran" ini. Dan ada idiom bahwa kata "silat" merupakan singkatan dari kata "silaturahmi".

Karena dalam bergaul masyarakat Banten yang dianggap bagus itu adalah mudah senyum dan banyak bersilaturahim. Istilahnya "Wakeh-wakeh Silaturohim" maksudnya mainnya jauh 
sehingga pengalamannya dan temannya banyak. Saking pentingnya silaturahim bagi masyarakat dan Jawara Banten ada istilah "aje ngebuke borokalane uong" karena hal itu dapat merusak silaturahim seseorang karena kejelekan seseorang diumbar-umbar.

Selain "Sedulur" ada juga konsep "Sebatur" yang masih turunan dari konsep deduluran. Konsep "Sebatur" ini lebih memperecepat untuk menyelesaikan masalah secara musyawarah dan akhirnya damai.

Namun untuk langkah pertama penyelesaian permasalahan bukanlah musyawarah karena pertamanya pasti ada rasa emosional dulu, karena ada konsep "Sedulur" atau "Sebatur" sehingga akhirnya baru bisa selesai secara musyawarah dan damai.

Artinya penyelesaian konflik itu ditelusuri dari hubungan, "Wong ngendi sire?" "Sire Siape?" (Orang mana kamu? Kamu siapa?) Istilahnya adalah "Ngededeleng Batur" dalam Bahasa Jawa Banten, karena pada awalnya kalau berkonflik mereka belum hubungan yang satu dengan yang lain, tapi setelah ditelusuri ternyata ada hubungan yang biasa disebut "Batur". Disinilah komunikasi orang Banten bermain, saling menghormati teman atau saudara. Terkadang teman atau "batur" lebih dari "dulur". Atau yang disebut dalam bahasa Banten0 biasa disebutkan "sire medulur be ning kite ning dulur be ngadoi wong lain memarki ning kite".

Jadi Jawara Banten dalam berkonflik tidak jadi besar dalam karena diselesaikan pada tingkat dini yaitu dalam tingkat hubungan, tujuannya agar masalahnya tidak berkepanjangan.

Ada istilah dalam Bahasa Banten yaitu "Ngeriung mempulung ngeberesi masalah" dan juga istilah "Dodok Ranggem". Yang berarti yang salah siapa itu nomor dua, yang pertama itu "Wong ngendi sire" (kamu siapa? Ada hubungan saudara dengan saya tidak? Baru masalahnya menjadi nomor dua.

Gestur salaman ketika selesai berkonflik itu juga menjadi penting untuk menyelesaikan unsur dendam, karena dengan salaman itu memperkuat agar masalahnya tidak berkelanjutan. Saat bersalaman biasanya diikuti dengan omongan "jaluk ampule, kule hilap jadi kagol".

Ada perubahan kultur dalam berkonflik di Banten, kalau dulu berkelahi biasanya ada istilah "wes ijen bae, ijen siji-siji ning alon-alon". Jadi seperti duel dan tidak berkelahi ramai-ramai. Sekarang sudah berkurang karena diselesaikan dulu dengan cara musyawarah.

Dalam lingkungan masyarakat Jawara Banten ada larangan yang tidak boleh dilakukan dalam pergaulan antar manusia, ada istilahya "Aje Julid, Aje ngelunjak, Aje Mencangak, Aje Syirika, Aje Ilok Ngebohong, Aje Ilok Ngulungani, Aje Ilok Makan Uong” karena kurang baik untuk dipakai dalam pergaulan.

\section{SIMPULAN}

Konsep "deduluran" merupakan konsep kunci di Banten khususnya komunitas Jawara. "deduluran" itu dalam rangka negosiasi. Seperti "deduluran bae lah" supaya lebih mengakrabkan diri. Seperti "dulur batur akur" atau seperti ada di kalangan keluarga kita. Maksudnya dengan teman dan dengan saudara itu akur, temanpun bisa dijadikan saudara. Pada saat ada konflik "kudu akur sedulur" itu biasanya nasehatnya. Yang penting jangan berbuntut panjang masalahnya dan selesai disitu.

Saran untuk penelitian lebih lanjut perlu dikomparasi hasil dari komunikasi konflik Jawara Banten dengan komunikasi konflik dengan budaya masyarakat di sekitarnya.

\section{DAFTAR PUSTAKA}

Adetunji, R.R \& Sze, K.P. 2012. Understanding Nonverbal Communication across Cultures: A Symbolic Interactionism Approach, I-come,1:1-8.

Bandiyah, B. 2010. Evolusi Jawara di Banten. (Studi Evolusi dari Bandit menjadi Pejabat). Jurnal Interaktif, 1(2).

Chen, G-M. 1989. Relationships of the Dimensions of Intercultural Communication Competence. Communication Quarterly, 37 (2), 118-133.

Firdausi, I.A. 2016. Jawara dalam Budaya Banten. (Studi Etnografi Komunikasi mengenai Jawara di Banten. Jurnal Lontar 4(3): 15-29.

Gudykunst, W. B. \& Ting-Toomey, S. (1988). Culture and interpersonal Communication. Newbury Park, CA: Sage. 
Hall, E. 1976. Beyond culture. New York: Doubleday.

Kim, D., Pan, Y. \& Park, H. S. (1998). High- versus low-context culture: A comparison of Chinese, Korean and American cultures. Psychology \& Marketing, 15(6), 507-521.

Samovar, L., Porter, R.E., McDaniel, E.R., Roy, C.S. 2012. Communication Between Cultures. Boston: Wadsworth Cengage Learning.

Sugiyono. 2013. Metode Penelitian Kuantitatif Kualitatif dan R \& D. Bandung: Alfabeta Veerger, K.J. 1993. Realitas Sosial. Jakarta:Gramedia Pustaka Utama

West, E.L \& Turner, L.H. 2007. Introducing Communication Theory: Analysis and Application. New York: McGraw-Hill Higher Education 